\section{Stress and its effects on horses reproduction}

\author{
Amal M. AboEl-Maaty \\ Animal Reproduction and Al Department, \\ Veterinary Division, National Research \\ Centre, Dokki, Giza, Egypt
}

\section{Abstract}

A total of 90 mares and horses were subjected to blood sampling for determining the effect of management (farm), reproductive condition, sex, age, breed and month of the year during breeding on circulating levels of cortisol and sex hormones. Blood samples were collected from December to the following June from four farms. Blood sera underwent testosterone, estradiol, progesterone and cortisol assaying using ELISA kits. Cortisol levels were significantly low in lactating mares during their foal heat but significantly high levels were recorded in both repeat breeder mares and horses used for racing. High and significant testosterone and estradiol levels were recorded in both stallions used for breeding especially after semen collection and early pregnant mares. Similar testosterone levels were recorded in both early pregnant mares and racing horses but high levels were recorded in stallions. Estradiol was high in both early pregnant and mares with endometritis but the highest levels were observed in stallions. Horses held in private farms had high cortisol levels compared to those of governmental farms. In contrast to mares, horses had low cortisol and high estradiol levels. Cortisol levels were high from April to June (Spring and early summer) compared to its levels from December to March (Winter). Arab horses had low cortisol compared to native and imported foreign breeds. In conclusion, environmental condition, exercise, breed, management and the purpose of raising horses all are affecting its cortisol levels.

\section{Introduction}

Interactions between the hypothalamicpituitary-adrenal and hypothalamic-pituitarygonadal axis are numerous, however, glucocorticoids have frequently been indicated as one major factor mediating the suppressive effects of stress on reproductive functions. In the horse, the dominant glucocorticoid in plasma is cortisol. ${ }^{1}$ Not only, glucocorticoids suppress reproductive functions at the hypothalamic, pituitary, ovarian and also uterine level in mares, 2 but also in women, ${ }^{3}$ rodents, ${ }^{4}$ sheep ${ }^{5}$ and cattle. ${ }^{6}$ Therefore, stressful events may contribute to low reproductive efficiency due to glucocorticoid mediated inhibition of reproduction in a variety of species.

Stress has been defined as any event resulting in increased activity of the hypothalamopituitary-adrenal (HPA) axis. ${ }^{7}$ The end result of HPA axis activation is a rise in plasma corticosteroid concentrations. Accordingly, plasma corticosteroids are often monitored experimentally to gauge an animal's perception of the stressfulness of various situations and clinically to evaluate the function of the axis. Stress and increased body temperature induced by racing may have negative effects on fertility. On the other hand, high quality nutrition and management of racing horses may have positive effects. ${ }^{8}$

In equine breeding, the mare is not only exposed to repeated restraint and gynaecological examinations, but also to other stressful events such as transportation to the breeding farm and loss of the normal environment and social companions; all together these events may cause increased secretion of glucocorticoids and cortisol. Exercise, ${ }^{9-11}$ transportation, 12 pain, ${ }^{13}$ social stress, ${ }^{14}$ acute exercise, 15 and sexual activityl6,17 increased cortisol in horses. A potential indicator of animal welfare is the absence of stress, but to date there is no standard definition of stress and no single biochemical assay system to measure stress. ${ }^{18}$ Repeated administration of dexamethasone to mares in oestrus is associated with decreased uterine oedema, suppression of LH and a high rate of ovulation failure. 19

Egypt holds different horse breeds pure Arabian, several European breeds and native breeds. Arabian horses are used for leisure, dancing and breeding. Most European and other imported breeds are used for riding, sports, training and few could be used for breeding. Native horses are mainly used for work, training and breeding. Horses are held in separate paddocks on private and governmental farms but management differs from farm to another and also according to the value of the horse or mare and purpose of raising it. Studies on effects of stress on reproduction are deficient in Egypt. To create a database for steroid reference values in horses and to assist in physiological characterization and diagnosis of endocrine disorders in horses, this study aims at investigating the circulating levels of cortisol as a marker of stress and sex hormones in relation to management (farm), age, gender, breed, month and reproductive status in horses.
Correspondence: Dr. Amal AboEl-Maaty, Animal Reproduction and AI Department, Veterinary Division, National Research Centre, Dokki, Giza 12311, Egypt. Tel. +202.0121278132.

E-mail amalaboelmaaty1@yahoo.com

Key words: cortisol, sex hormones, gender, age, reproduction, horses.

Acknowledgements: the author wishes to thank the farms that allowed blood sampling, gynecological ultrasound examination and semen collection before sampling.

Received for publication: 4 September 2011. Accepted for publication: 21 October 2011.

This work is licensed under a Creative Commons Attribution NonCommercial 3.0 License (CC BYNC 3.0).

(C) Copyright A.M. AboEl-Maaty, 2011

Licensee PAGEPress, Italy

Veterinary Science Development 2011; 1:e13

doi:10.4081/vsd.2011.e13

\section{Materials and Methods}

\section{Animals}

A total of 90 horses (1-12 years old) were used in the present study. They were divided into groups according to sex, purpose of rearing and reproductive condition into females $(\mathrm{n}=63)$ and males $(\mathrm{n}=27)$. Females included fillies $(n=16) \leq 2$ years old, normal cycling mares $(n=16)$, sub-clinical endometritis (repeat breeders, $n=21$ ), early pregnant $(n=5)$ $<45$ days pregnant and lactating during the foal heat $(n=5)$. Males included colts $<2$ years old $(n=4)$, stallions of age 5-12 years old $(\mathrm{n}=16)$ and castrated horses used for racing $(n=7)$. Mares with repeat breeder history $(n=21)$ were subjected to ordinary microbial examination to identify the causative microorganisms. Others were apparently healthy. Four horse-holding farms were used for collecting blood samples. The first two farms are governmental and the other two are private.

\section{Sampling protocol}

Blood samples were drawn from the jugular vein from all groups between 10:00 and 11:00 a.m. to minimize the effect of circadian rhythm on hormone measurements. Additional samples of the racer group were collected shortly after race to exclude doping in fresh plain vial for sera harvesting. Sampling was performed in mares after gynecological examination for detection of mature follicle or early pregnancy and in stallions after semen collection. 


\section{Hormone assaying}

Serum cortisol, ${ }^{20}$ progesterone, ${ }^{21}$ estradioli22 and total testosterone 23 concentrations were analyzed using a commercially available Enzyme immunoassay kit supplied by Medical Biological Service S.r.l. (Milano, Italy). Sensitivity of the assay was $0.4 \mu \mathrm{g} / \mathrm{dL}$, intraand inter-assay CV were $2.9 \%$ and $3.8 \%$, respectively for cortisol; $10 \mathrm{pg} / \mathrm{mL}, 9.1 \%$ and $9.8 \%$ for estradiol; $0.1 \mathrm{ng} / \mathrm{mL}, 10.6 \%$ and $12.6 \%$ for progesterone; $0.022 \mathrm{ng} / \mathrm{mL}, 6.6 \%$ and $7.3 \%$ for testosterone.

\section{Statistical analysis}

The effect of reproductive condition, gender, age and management (farm) in addition to month of sampling was studied using simple one way ANOVA and the statistical significance between means was compared using Duncan multiple range test; $(\mathrm{P}<0.05)$ was considered significant. Student $t$-test was also performed to study the effect of gender on cortisol and sex hormones. All data are presented as means \pm standard error (SE) of the means. Pearson correlation coefficients were also performed between the assayed hormones in both sexes. All tests were performed using computer package of the statistical analysis system SPSS. ${ }^{24}$

\section{Results}

\section{Gender effect}

In contrast to the insignificantly high cortisol in females compared to males, the reverse is clear in estradiol levels. Testosterone levels are significantly $(\mathrm{P}=0.038)$ low in females (Table 1) compared to males.

In females, correlation made between cortisol and testosterone is positive and significant ( $r=0.30 ; P=0.039)$ but that with estradiol is highly significant strong and positive $(\mathrm{r}=0.42$; $\mathrm{P}=0.009$ ). The correlation between progesterone and estradiol is more strong and highly significant $(\mathrm{r}=0.55 ; \mathrm{P}=0.0001)$ than that with testosterone $(\mathrm{r}=0.36 ; \mathrm{P}=0.011)$. Similarly, strong positive and highly significant correla- tion is found between estradiol and testosterone ( $\mathrm{r}=0.47 ; \mathrm{P}=0.008)$. In males, cortisol has a high negative but not significant correlation with estradiol $(\mathrm{r}=-0.47 ; \quad \mathrm{P}=0.064)$. Estradiol is positively correlated with testosterone but correlation even high is not significant $(\mathrm{r}=0.38 ; \mathrm{P}=0.28)$.

\section{Breed effect}

The Arabian horses have significantly low cortisol, testosterone and progesterone levels (Table 1) compared to both Foreign and native. Native horses and mares have significant low estradiol compared to Arabians and foreign ones.

\section{Farm effect}

Mares in farm 1 have significant low cortisol levels compared to the other three farms (Table 1).

\section{Reproductive condition}

Cortisol levels are significantly low in lactating mares during early postpartum (foal heat) but its levels are high in stallions (Table 2) and early pregnant mares followed by colts, fillies and cyclic mature mares Significant high levels of cortisol are found in only repeat breeder mares due to sub-clinical endometritis and also race horses. Testosterone is significantly low in fillies and high in cyclic and early pregnant mares. Similar testosterone levels are recorded in repeat breeder and early pregnant mares. Estradiol levels are significantly in both early pregnant mares within the female group and stallions within the male group. Low estradiol levels are recorded in both colts and fillies (Table 2).

\section{Month}

Cortisol increases in its level from December (winter) to June (late spring) and this increase is accompanied by an increase in both testosterone and estradiol (Table 3).

\section{Discussion}

The effect of racing on males' cortisol levels just after race is obvious in the present work. Although this increase was not correlated with any sharp alteration in both testosterone and estradiol levels compared to stallions used for breeding only. Similarly, twice cortisol levels were found after the country round compared to its levels before the country round. $250 \mathrm{n}$ the other hand, during competitions, experienced jumpers have significantly lower concentrations of plasma cortisol than inexperienced

Table 1. Effect of sex, breed and farm management on levels of cortisol, testosterone, estradiol and progesterone.

\begin{tabular}{lccccc} 
& N & Cortisol & Testosterone & Estradiol & Progesterone \\
Breed & & 0.0001 & 0.01 & 0.007 & 0.12 \\
Arab & 45 & $14.81 \pm 1.22^{\mathrm{a}}$ & $2.68 \pm .32^{\mathrm{a}}$ & $370.18 \pm 2.04 \mathrm{~b}$ & $3.55 \pm 0.34$ \\
\hline Foreign & 20 & $23.67 \pm 1.37 \mathrm{~b}$ & $4.79 \pm 0.53^{\mathrm{b}}$ & $322.62 \pm 21.57 \mathrm{ab}$ & $5.16 \pm 1.05$ \\
Native & 25 & $22.69 \pm 1.49^{\mathrm{b}}$ & $3.77 \pm 0.49^{\mathrm{ab}}$ & $267.93 \pm 25.99 \mathrm{a}$ & $4.54 \pm 0.57$ \\
\hline Farm & & 0.001 & 0.002 & 0.13 & 0.0001 \\
1 & 10 & $10.75 \pm 2.17 \mathrm{a}$ & $3.82 \pm 0.43^{\mathrm{ab}}$ & $328.00 \pm 14.23$ & $3.71 \pm .309^{\mathrm{a}}$ \\
2 & 62 & $18.85 \pm 1.04^{\mathrm{b}}$ & $3.12 \pm 0.41 \mathrm{ab}$ & $314.72 \pm 16.79$ & $4.84 \pm 0.52^{\mathrm{ab}}$ \\
3 & 9 & $24.77 \pm 1.66^{\mathrm{b}}$ & $2.24 \pm 0.53^{\mathrm{a}}$ & $426.56 \pm 26.79$ & $6.46 \pm 1.593^{\mathrm{b}}$ \\
4 & 9 & $23.59 \pm 3.06^{\mathrm{b}}$ & $4.88 \pm 1.14 \mathrm{~b}$ & $302.59 \pm 29.35$ & $5.4560 .86^{\mathrm{b}}$ \\
Gender & & 0.13 & 0.038 & 0.14 & \\
\hline Female & 63 & $19.86 \pm 1.05$ & $2.98 \pm 0.34$ & $313.8 \pm 16.65$ & \\
Male & 27 & $16.93 \pm 1.73$ & $4.69 \pm 0.42$ & $360.9 \pm 26.26$ & \\
\hline
\end{tabular}

a,bMeans with different superscripts are significantly different at $\mathrm{P}<0.05$.

Table 2. Effect of reproductive condition, gender and age on mean levels of cortisol, testosterone, progesterone and estradiol.

\begin{tabular}{|c|c|c|c|c|c|c|c|c|c|}
\hline & \multirow[b]{2}{*}{ Fillies } & \multicolumn{4}{|c|}{ Females } & \multicolumn{3}{|c|}{ Males } & \multirow[t]{2}{*}{ P-value } \\
\hline & & Cyclic & $\begin{array}{l}\text { Early } \\
\text { pregnant }\end{array}$ & $\begin{array}{c}\text { Subclinical } \\
\text { endomet }\end{array}$ & Lactating & Colts & Stallions & Racers & \\
\hline $\mathrm{N}$ & 16 & 16 & 5 & 21 & 5 & 4 & 16 & 7 & \\
\hline Age /year & $1-2.5$ & \multicolumn{4}{|c|}{$5-12$} & $<1.5$ & $3-11$ & & \\
\hline Cortisol & $21.12 \pm 1.40 c$ & $14.32 \pm 1.61^{b}$ & $17.97 \pm 1.99 \mathrm{bc}$ & $26.64 \pm 1.06 \mathrm{~d}$ & $6.56 \pm 1.683^{\mathrm{a}}$ & $18.49 \pm 3.07 \mathrm{bc}$ & $13.21 \pm 1.94 b$ & $24.65 \pm 3.31 \mathrm{~d}$ & 0.0001 \\
\hline Testosterone & $1.38 \pm 0.29 \mathrm{a}$ & $2.91 \pm 0.65^{\mathrm{ab}}$ & $4.88 \pm 0.20 \mathrm{bc}$ & $4.55 \pm 0.86^{\mathrm{bc}}$ & $2.87 \pm 0.12 \mathrm{ab}$ & $3.28 \pm 1.37 \mathrm{ab}$ & $5.66 \pm 0.74 \mathrm{c}$ & $4.72 \pm 1.31 \mathrm{bc}$ & 0.0001 \\
\hline Estradiol & $241.22 \pm 15.03^{\mathrm{a}}$ & $305.76 \pm 26.24 \mathrm{a}$ & $433.19 \pm 71.68 \mathrm{~b}$ & $410.79 \pm 28.10 c$ & $313.84 \pm 16.65 \mathrm{ab}$ & $271.72 \pm 69.95^{\mathrm{a}}$ & $473.73 \pm 7.78 \mathrm{c}$ & $302.59 \pm 33.72^{\mathrm{a}}$ & 0.0001 \\
\hline Progesterone & $2.4 \pm 0.58^{\mathrm{a}}$ & $4.64 \pm 1.03^{b}$ & $5.89 \pm 1.07^{\mathrm{b}}$ & $6.3 \pm 0.84^{b}$ & $1.62 \pm 0.33^{\mathrm{a}}$ & & & & 0.0001 \\
\hline
\end{tabular}

\footnotetext{
a-dMeans with different superscripts are significantly different at $\mathrm{P}<0.05$.
} 
jumpers, suggesting that horses become conditioned to the psychological stress of the show environment. ${ }^{26}$ So stallions' fertility did not suffer from racing during the mating year. ${ }^{8}$ In stallions of the present investigation, cortisol levels was similar to that of normal cyclic mares but was lower than those horses used for racing and even colts, so sexual excitation in stallions had low effect on cotrisol levels compared to racing or age. In contrast, cortisol is secreted in response to sexual stimulation, exercise, and twitching but in geldings, cortisol is released in response to exercise, and twitching. 27

Although racing increase cortisol levels compared to stallions after semen collection or natural breeding but testosterone levels were higher in stallions than in race horses. This may referred to that race horses are subjected to multiple stressors such as transport to the race area, the race itself and the presence of large numbers of people around horses before and after race for checking, grooming and dressing. The decrease in testosterone levels in race horses compared to stallions may refered to the use of castrated horses for racing to facilitate controlling them and this testosterone originated from their adrenals. Moreover, chronic stress decreases testosterone production but acute stressors have a much less predictable influence on testosterone concentrations, with authors reporting no changes, ${ }^{28}$ decrease ${ }^{29}$ or even increase ${ }^{30}$ in testosterone. The manner in which an organism reacts to stress is not only influenced by the type, duration and intensity of the stressor; it also depends on the presence of circulating sexual steroid hormones. ${ }^{31}$

The higher cortisol concentrations in both fillies and colts (younger horses) of the present study compared to mature normal cycling mares and stallions agree with Fazio et al., ${ }^{32}$ who reported that growth affected cortisol values and cortisol concentrations is positively correlated with body weight in both colts $(\mathrm{r}=0.80 ; \mathrm{P}=0.001)$ and fillies $(\mathrm{r}=0.82$; $\mathrm{P}=0.001$ ) during growth from birth to weaning. Growth and weaning could modulate the opioid system and pituitary-adrenocortical axis of Thoroughbred foals. ${ }^{32}$ High cortisol levels have been observed just before birth ${ }^{33}$ and in the first $2 \mathrm{~h}$ after birth of the term foals. ${ }^{34}$

In agreement with Escribano et al. 35 gender has no significant effect on cortisol levels either at rest or in response to exercise. In contrast to Fazio et al., ${ }^{32}$ females had insignificant high cortisol than males whatever they were fillies or mature cycling mares or both and that most fillies and colts of the present work are older than Fazio's study.

In this study, repeat breeder mares underwent several gynecological examinations before breeding to access size of mature follicles and after natural breeding to detect early

Table 3. Effect of month during the breeding on mean levels of cortisol, testosterone, progesterone and estradiol.

\begin{tabular}{lcccc} 
Month & Cortisol & Testosterone & E2 & P4 \\
December & $9.52 \pm 4.63^{\mathrm{a}}$ & $4.51 \pm 0.375^{\mathrm{ab}}$ & $287.56 \pm 15.65^{\mathrm{a}}$ & $3.51 \pm 0.19^{\mathrm{a}}$ \\
January & $15.04 \pm 5.03^{\mathrm{a}}$ & $3.20 \pm 0.48^{\mathrm{a}}$ & $217.75 \pm 51.14^{\mathrm{a}}$ & $5.47 \pm 2.72^{\mathrm{a}}$ \\
\hline February & $16.57 \pm 2.28^{\mathrm{ab}}$ & $2.05 \pm 0.41^{\mathrm{a}}$ & $285.25 \pm 33.81^{\mathrm{a}}$ & $4.01 \pm 0.90^{\mathrm{a}}$ \\
March & $17.99 \pm 1.12^{\mathrm{ab}}$ & $3.23 \pm 0.50^{\mathrm{a}}$ & $327.37 \pm 17.06^{\mathrm{ab}}$ & $5.12 \pm 0.83^{\mathrm{a}}$ \\
\hline April & $25.88 \pm 2.15^{\mathrm{b}}$ & $4.97 \pm 0.54 \mathrm{ab}$ & $431.58 \pm 43.56^{\mathrm{b}}$ & $9.15 \pm 1.36^{\mathrm{b}}$ \\
May & $26.79 \pm 1.66^{\mathrm{b}}$ & $5.46 \pm 1.04^{\mathrm{b}}$ & $328.00 \pm 14.23 \mathrm{ab}$ & $4.66 \pm 0.92^{\mathrm{a}}$ \\
\hline June & $27.65 \pm 4.95^{\mathrm{b}}$ & $5.52 \pm 0.53^{\mathrm{b}}$ & $484.73 \pm 21.14 \mathrm{~b}$ & $6.39 \pm 0.67 \mathrm{ab}$ \\
PValue & 0.001 & 0.051 & 0.029 & 0.015 \\
\hline
\end{tabular}

a,bMeans with different superscripts are significantly different at $\mathrm{P}<0.05$.

pregnancy using ultrasound and sometimes twitching is used in addition to moving the animal to the examination spot and even detection of infection all these factors may increase cortisol levels to values near to those of horses after race. Although gynaecological examinations in the mare seem to act as stressors and increase cortisol secretion but this does not negatively influence fertility and in animals familiar with that procedure concentrations are not elevated. ${ }^{36}$ However, long-term exposure as in teaching or research mares results in accustomation. In contrast to cattle and sheep, no effects of cortisol on fertility parameters (oestrus duration, pregnancy rates) could be found in the horse. ${ }^{36}$

Season of breeding mares in Egypt starts from October till the end of the following May in most governmental farm and private farms to avoid the adverse environmental conditions and the absence of the green palatable Egyptian clover Barseem (Trifolium Alexandrinum) during hot summer. Whatever the animals are adapted to the hot summer temperature and increased humidity, the increase in cortisol levels during May and June may be attributed to the increase in heat stress where environmental temperature exceeds $30^{\circ} \mathrm{C}$. As well as ambient temperatures higher than $30^{\circ} \mathrm{C}$ increase cortisol levels. ${ }^{37}$

Early pregnant mares in this study were having high testosterone and estradiol compared to normal cyclic and lactating mares during their foal heat but such increase has been ascribed to equine chorionic gonadotropin (eCG) stimulation of luteal testosterone synthesis. ${ }^{38}$ Moreover, testosterone levels were high at estrous in mares peripheral plasma and 11-13 days before the next estrous either before or after the fall in progesterone levels. ${ }^{39}$ Testosterone was also found to increase from the very beginning of pregnancy, reaching peak values 10 times higher than the basal values at the seventh month and then return to basal values by the week after parturition. Testosterone binding by plasma proteins was investigated in non-pregnant and pregnant mares throughout gestation. ${ }^{40}$ Maternal gonads would be responsible for the testosterone increase in early pregnancy, during the period of pregnant mare serum gonadotropin production, and the feto-placental unit for the subsequent increase. 40

The presence of testosterone in peripheral blood of cyclic normal and repeat breeder mares due to sub-clinical endometritis of the present study is also recorded in mare follicular fluid at a concentration, which is double higher than that in peripheral plasma, suggesting that the follicle may contribute to the production of circulating testosterone. A biosynthetic pathway for estradiol-17 beta which involves testosterone is therefore likely to occur in the mare ovary.41 In domestic mangolian horses, cortisol (98.70\%) is the predominant steroid, followed by aldosterone $(0.37 \%)$, androstenedione (0.35\%), 17-0H-progesterone $(0.21 \%)$, estradiol $(0.17 \%)$, progesterone $(0.14 \%)$, and testosterone $(0.06 \%) .42$

In conclusion, the change in horse management from farm to different breed, month, infection and racing increases stress and in turn the most common physiological response to stress is an increase in circulating cortisol levels.

\section{References}

1. Bottoms GD, Roesel OF, Rausch FD, Akins EL. Circadian variation in plasma cortisol and corticosterone in pigs and mares. Am J Vet Res 1972;33:785-90.

2. Kalantaridou SN, Makrigiannakis A, Zoumakis E, Chrousos GP. Stress and the female reproductive system. J Reprod Immunol 2004;62:61-8.

3. Rabin DS, Johnson EO, Brandon DD, et al. Glucocorticoids inhibit estradiol-mediated uterine growth: possible role of the uterine estradiol receptor. Biol Reprod 1990;42:7480.

4. Smith ER, Johnson J, Weick R, et al. 1971. Inhibition of the reproductive system in immature rats by intracerebral implanta- 
tion of cortisol. Neuroendocrinology 1971;8:94-106.

5. Macfarlane MS, Breen KM, Sakurai H, et al. Effect of duration of infusion of stresslike concentrations of cortisol on follicular development and the preovulatory surge of LH in sheep. Anim Reprod Sci 2000;63:16775 .

6. Mann GE. Pregnancy rates during experimentation in dairy cows. Vet J 2001; 161:301-5.

7. Harbuz MS, Lightman SL. Stress and the hypothalamo-pituitary-adrenal axis: acute, chronic and immunological activity. J Endocrinol 1992;134:327-39.

8. Sairanen J, Katila T, Virtala AM, Ojala M. Effects of racing on equine fertility. Anim Reprod Sci 2011;124:73-84.

9. Snow DH, Mason DK, Ricketts SW, Douglas TA. Post-race blood biochemistry in thoroughbreds. In: DH Snow, SGB Persson and RJ Rose (eds.) Equine Exercise Physiology, pp. 389-407. Burlington Press, Cambridge, UK, 1982.

10. Marc M, Parvizi N, Ellendorff F, et al. Plasma cortisol and ACTH concentrations in the warm blood horse in response to standardized treadmill exercise test as physiological markers for evaluation of training status. J Anim Sc. 2000;78:193646.

11. Gordon ME, McKeever KH, Betros CL, Manso Filho HC. Exercise induced alterations in plasma concentrations of ghrelin, adiponectin, leptin, glucose, insulin, and cortisol in horses. Vet J 2007;173:53240.

12. Baucus KL, Ralston SL, Nockels CF, et al. Effects of transportation on early embryonic death in mares. J Anim Sci 1990;68:34551.

13. Merl S, Scherzer S, Palme R, Möstl E. 2000. Pain causes increased concentrations of glucocorticoid metabolites in horse feces. J Equine Sci 2000;20:586-90.

14. Alexander SL, Irvine CHG.. The effect of social stress on adrenal axis activity in horses: the importance of monitoring corticosteroid-binding globulin capacity. J Endocrinol 1998;157:425-432.

15. Alexander SL, Irvine CHG, Ellis MJ, Donald RA. The effect of acute exercise on the secretion of corticotropinreleasing factor, arginine vasopressin, and adrenocorticotropin as measured in pituitary venous blood from the horse. Endocrinology 1991;128:65-72.

16. Tamanini C, Giordano N, Chiesa P, Smn E. Plasma cortisol variations induced in the stallion by mating. Acta Endocrinol-Cop 1983;102:447-50.
17. Rabb MH, Thompson DL Jr., Barry BE, et al. 1989. Effects of sexual stimulation, with and without ejaculation, on serum concentrations of LH, FSH, testosterone, cortisol and prolactin in stallions. $\mathrm{J}$ Anim Sci 1989;67:2724-9.

18. Hofer H, East ML. Biological conservation and stress. Adv Stud Behav 1998;27:405525.

19. Ferris RA, McCue PM. The effects of dexamethasone and prednisolone on pituitary and ovarian function in the mare. Equine Vet J 2010;42:438-43.

20. Check JH, Ubelacker L, Lauer CC. Falsely elevated steroidal assay levels related to heterophil antibodies against various animal species. Gynecol Obstet Invest 1995;40:139-40.

21. Abraham GE, Odell WD, Swerdloff RS, Hopper K. Simultaneous radioimmunoassay of plasma FSH, LH, progesterone, 17hydroxyprogesterone, and estradiol-17 beta during the menstrual cycle. J Clin Endocrinol Metab 1972;34:312-8.

22. Moll GW Jr, Rosenfield RL. Estradiol inhibition of pituitary luteinizing hormone release is antagonized by serum proteins. J Steroid Biochem 1986;25:309-14.

23. Marcus GJ, Durnford R. Simple -linked immunoassay for testosterone. Steroids 1985;46:975-86.

24. SPSS. PC software, ver. 16. SPSS Inc., Chicago, IL, USA, 2007.

25. Peeters M, Sulon J, Serteyn D, Vandenheede M. Assessment of stress level in horses during competition using salivary cortisol: preliminary studies. J Vet Behav 2010;5:216 (abstract).

26. Clayton HM. Terminology for the description of equine jumping kinematics. $\mathrm{J}$ Equine Vet Sci 1989;9:341-7.

27. Colborn DR, Thompson DL Jr, Roth TL, et al. Responses of cortisol and prolactin to sexual excitement and stress in stallions and geldings. J Anim Sci 1991;69:2556-62.

28. Wilkerson JE, Horvath SM, Gutin B. 1980. Plasma testosterone during treadmill exercise. J Appl Physiol 1980;49:249-53.

29. Cumming DC, Wall SR, Quinney HA, Belcastro AN. Decrease in serum testosterone levels with maximal intensity swimming exercise in trained male and female swimmers. Endocrinol Res 1987;13:31-41.

30. Cumming DC, Brunsting LA, Strich G, et al. Reproductive hormone increases in response to acute exercise in men. Med Sci Sport Exerc 1986;18:369-373.

31. Turner AI, Canny BJ, Hobbs RJ, et al. Influence of sex and gonadal status of sheep on cortisol secretion in response to
ACTH and on cortisol and LH secretion in response to stress: importance of different stressors. J Endocrinol 2002;173:113-22.

32. Fazio E, Medica P, Grasso L, Messineo C, Ferlazzo A. Changes of circulating $B$ endorphin, adrenocorticotrophin and cortisol concentrations during growth and rearing in Thoroughbred foals. Livest Sci 2009;125:31-6.

33. Silver M, Fowden AL, Knox J, et al. Relationship between circulating triiodothyronine and cortisol in the perinatal period in the foal. J Reprod Fertil Suppl 1991;44:619-626.

34. Silver M, Ousey JC, Dudan FE, et al. Studies on equine prematurity 2: post natal adrenocortical activity in relation to plasma adrenocorticotrophic hormone and catecholamine levels in term and premature foals. Equine Vet J 1984;16:278-86.

35. Escribano BM, Castejo FM, Santisteban R, et al. Gender differences in non-specific immune response to exercise in the lactate threshold: A study in equine athletes. Res Vet Sci 2008;85:250-6.

36. Berghold P, Möstl E, Aurich C. Effects of reproductive status and management on cortisol secretion and fertility of oestrous horse mares. Anim Reprod Sci 2007;102: 276-85.

37. Rammerstorfer C, Potter GD, Brumbaugh GW, et al. Physiologic responses of acclimatized or non-acclimatized mature reining horses to heat stress: I. Heart rate, respiration rate, lactate, rectal temperature, cortisol and packed cell volume. J Equine Vet Sci 2001;21:431-8.

38. Daels PF, Chang GC, Hansen B, Mohammed HO. Testosterone secretion during early pregnancy in mares. Theriogenology 1996;45:1211-9.

39. Silberzahn P, Quincey D, Rosier C, Leymarie P. Testosterone and progesterone in peripheral plasma during the oestrous cycle of the mare. J Reprod Fertil 1978;53:1-5.

40. Silberzahn P, Zwain I, Martin B. Concentration increase of unbound testosterone in plasma of the mare throughout pregnancy. Endocrinology 1984;115:416-9.

41. Silberzahn P, Dehennin L, Zwaïn IH, Leymarie P. Identification and measurement of testosterone in plasma and follicular fluid of the mare, using gas chromatography-mass spectrometry associated with isotope dilution. J Endocrinol 1983; 97:51-6.

42. Haffner JC, Fecteau KA, Eiler $\mathrm{H}$, et al. Blood steroid concentrations in domestic Mongolian horses. J Vet Diagn Invest 2010;22:537-43. 